\title{
ON THE JESUIT-MARONITE PROVENANCE OF LEBANON'S CRIMINALIZATION OF HOMOSEXUALITY
}

\author{
IVAN STRENSKI \\ Distinguished Professor of Religious Studies, Emeritus, University of California, Riverside
}

\begin{abstract}
Article 534 of the Lebanese Penal Code, effectively, criminalizes homosexual practices. Most commentators have claimed that its existence in modern Lebanon is a "colonial relic," specifically of the French Mandate, I920-I946. But since I79I, French penal codes have not criminalized same-sex relations. I argue, instead, that Article 534 was the product of native religious, legal, and moral thinking among the Maronites, reinforced by the Thomistic and post-Tridentine moral theology taught in Lebanon by the Jesuit missions. Thomistic and post-Tridentine moral theology classified same-sex relations as worthy of condemnation as "unnatural acts" - the same language used in Article 534. Therefore, as a product of Lebanese political and religious sectarianism, Article 534 is a specific case of a congenial collaboration of Jesuit moral theology and a conservative Maronite ethical and legal koine.
\end{abstract}

KEYWORDS: Maronite, Article 534, Lebanon, same-sex relations, Aquinas, sectarianism, Jesuit, confessionalism, France, conviviendum

A Presbyterian missionary was once asked, if he was going to build a school in a certain town of the Lebanon. "Two schools"! he answered. "Yes? How is that?" "Oh, I'll put up one for myself, and, within a week or two, the Jesuits will be at work with another." ${ }_{-}$

\section{THE UPS AND DOWNS OF ARTICLE 534}

On Saturday, March 30, 20I9, Judge Peter Germanos, Lebanon's top military prosecutor, ruled that same-sex acts are not criminal acts. Germanos thus ruled against the criminalization of "unnatural sexual relations," as stated in controversial Article 534 of the Lebanese Penal Code. But what counts as "unnatural sexual relations" has been disputed. Sara Mandour writes, "This vague term implies every sexual practice that does not involve marital coitus, and thus does not serve

I Walter M. Drum, “Our Mission in Syria," Woodstock Letters, no. 28 (I908): 230-38, 324-44, at 233, https:// jesuitarchives.omeka.net/files/show/724. 
the aim of procreation and reproduction of new citizens within a nuclear heterosexual family (i.e. homosexuality, sex outside of marriage, anal sex, and so on)." ${ }^{2}$ Complicating matters, the term "unnatural sexual relations" in Germanos's ruling represents a 2002 change from an earlier, 1943, formulation of Article 534 in terms of "unnatural sexual intercourse." 3

Interestingly, this is not the first recorded application of this kind of legal thinking in Lebanon, nor the first time Lebanese judges have challenged the classification of same-sex relations as "unnatural." Judgments have tended to swing back and forth on the whether the illegality of same-sex relations can be conceived in terms of their being "unnatural." 4 In 2009, Judge Mounir Suleiman ruled that consensual sexual intimacy could not be considered "against nature": "Man is part of nature and one of its elements, so it cannot be said that any one of his practices or any one of his behaviours goes against nature, even if it is criminal behavior, because it is nature's ruling." 5

Similarly, in 201 5 , nine people, suspected of being gay or transgender, were arrested in a suburb of Beirut. Yet, a criminal court declined to convict them-once more- under Article 534's classification of "unnatural offenses." The judge's rationale for acquittal stated simply that "homosexuals have a right to human and intimate relationships with whoever they want, without any interference or discrimination in terms of their sexual inclinations, as it is the case with other people." 6

On the other hand, LGBTQ activist Ghassan Makarem observes that expanding the scope of Article 534 in 2002 by replacing the term "intercourse" with "relations," the law became more capacious and thus more threatening to the LGBT community.7 Another commentator complained that as late as 2016, "the state harasses and tortures its own citizens based solely on their sexual orientation and gender identity." 8 Further, as late as 2017 "The Criminal Court in Beirut has refused to overturn the obstacles to the homosexuals or lesbians, or to exempt them from punishment, because the Lebanese Penal Code condemns such a crime and does not tolerate it, even if it is legislated outside Lebanon." 9 Apparently, then, the labeling of same-sex relations as "unnatural" still carried sufficient weight in certain quarters to judge them illegal. ${ }^{\circ}$

2 Sara Mandour, "Potential Change in Media Discourse on Sexuality in Lebanon: 'Cinema Plaza' and Beyond," Reuters Institute Fellowship Paper, Reuters Institute for the Study of Journalism, 2013, 6, https://reutersinstitute. politics.ox.ac.uk/sites/default/files/research/files/Potential\% 2520 Change $\% 2520$ in $\% 2520$ Media $\% 2520$ Discourse $\%$ $252000 \% 2520$ Sexuality \% 2520 in \% 2520 Lebanon.pdf.

3 Ghassan Makarem, “The Story of HELEM,” Journal of Middle East Women's Studies 7, no. 3 (20I I): 98-I I 2, at IO4.

4 US Department of State, "Lebanon," in Country Reports on Human Rights Practices for 2010 (Washington, DC: U.S. Government Printing Office, 20I0), 2:2169-88, at 2I 86, https://2009-20I7.state.gov/j/drl/rls/hrrpt/2010/nea/ I 54466 .htm.

5 Human Dignity Trust, "Lebanon” (quoting Judge Mounir Suleiman in translation), accessed August I8, 2020, https://www.humandignitytrust.org/country-profile/lebanon/.

6 As quoted in "Lebanon: Same-Sex Relations Not Illegal: Homosexuality Not an 'Unnatural Offense,' Appeals Court Rules,” Human Rights Watch, July I9, 2018, https://www.hrw.org/news/2018/07/I9/lebanon-samesex-relations-not-illegal.

7 Makarem, "The Story of HELEM," I04.

8 Sarabrynn Hudgins, “Why Is Lebanon Still Using Colonial-Era Laws to Persecute LGBTQ Citizens?,” Slate, May 3I, 20I 6, https://slate.com/human-interest/20I6/05/lebanon-still-uses-colonial-era-laws-to-persecute-lbgtq-citizens.html.

9 Ali al-Moussawi, "al-Alaqat al-Mithliyyah Jurmun Yuàqib àlayhi al-Qanun al-Lubnani” [Same-sex relations is a crime punishable by Lebanese law] Mahkama, July 2017, http://www.mahkama.net/?p=256. Translation from the Arabic provided by Dr. Ayman Shabana.

Io ALEF et al., Civil Society Report on the Implementation of the International Covenant on Civil and Political Rights in Lebanon: I22 Session of the Human Rights Committee, March 2018, 3, https://tbinternet.ohchr.org/ Treaties/CCPR/Shared\% 20Documents/LBN/INT_CCPR_CSS_LBN_3024I_E.pdf. 


\section{ARTICLE 534: LAÏC COLONIAL RELIC?}

Commentators have lately puzzled about the genealogy of Lebanon Penal Code's Article 534, and with it, the conspicuous presence of its discourse of the natural and unnatural. Below I argue that most, if not all, attempts to account for Article 534 have generally failed because they have been blinkered by secularist tendencies of thought. Such a tendency presumes that the provenance and persistence of Article 534 are matters of simple, colonial state administrative rule. However, one may admire Edward Said's critique of Orientalism, it has made it too easy to assume that a statute like Article 534 represents a vestige of the purely external conditions of foreign imperial rule, and, most often, of the colonialism of the laïc French state administration.

Over against a purely secular account of the appearance of Article 534, I argue that Lebanon's tangled religious history is the indispensable starting point for making sense of this controversial statute. At the risk of distorting what is a complex story of subtle religious and social interaction, I offer a foretaste-in highly compressed form - of the detailed story I tell about what cultural conditions made a law like Article 534 possible. Despite their formal loyalty to Rome, the post-Tridentine Roman church made Lebanon's Eastern Rite Maronite targets for an intense conversion effort of Latinizing Lebanese religious thought and practice. Notably, the Vatican's missionary efforts in Lebanon replicated the same religious sectarianism-confessionalism-that then dominated the post-Reformation West, possibly giving form to a preexisting Maronite ethnoreligious nationalism. The shock troops of the Vatican's sectarian and Latinizing campaigns were the Jesuit missionaries. The Jesuits realized Vatican ambitions for harmonizing the Maronite church with Rome by establishing an extensive network of schools and seminaries. As the Latinizing process deepened, indigenous traditions of ethno-nationalist Maronite moral-legal theology gradually merged into a unitary culture of Jesuit-Maronite Lebanese Catholicism. As I show below, the legal thinking culminating in Article 534 emerged out of this Jesuit-dominated religious culture. I do not by any means write off other sectarian Lebanese factors as facilitating the appearance of Article 534, such as the influence of the Druze or Lebanon's several varieties of Muslims. But I argue that these are the principal protagonists behind the appearance of Article 534 .

I thus argue that the emergence of Article 534 reflects a failure to comprehend the complex role of religion in the making of modern Lebanese sectarian culture and politics. Again, largely for practical purposes-but not only-I focus on the influential role of Catholic, mostly Jesuit, missionary activity in forming Lebanese sectarianism. The Jesuits served both as ancillaries to secular colonialism but also as independent confessional actors, rooted equally well both in the cultures of colonizer and colonized, alike. Here, the "usual suspects"-the French Mandate authorities-take a back seat to the massive, long-lived Jesuit missionary enterprises of the Vatican in the Levant. Only by understanding the religious missionary history of modern Lebanon, replete with the story of Maronite receptivity, does Article 534's ostensibly theological language of the "unnatural" make sense. Postcolonial theory's understandable emphasis upon the brute power of European imperial force in shaping Middle Eastern history has tended, instead, to distract from the formative agency of what turns out in the case of Lebanon to be the collaborative sectarian religious partnership of Maronite Catholics and Jesuits.

What then of the first misunderstanding of the genealogy of Article 534 as a "relic" of Mandate France's impositions upon the Lebanese? Much cited in this regard is a Human Rights Watch report suggesting that Article 534 was a supposedly French Mandate "colonial relic." II Echoes

I I Human Rights Watch, “Lebanon: Same-Sex Relations Not Illegal”; Women's Rights Report: Discrimination in the Punishment of Women (Tokyo: Human Rights Now, 2018), http://hrn.or.jp/eng/wp-content/uploads/2018/o7/ Discrimination-in-the-Punishment-of-Women-Report-HRN-July-2or8.pdf; Rayana Khalaf, "Homosexuality 
of this charge reverberate widely through the literature. ${ }^{\mathrm{I2}}$ Illustrative of the "colonial relic" idea's reach, as recently as 20I 8, in an undergraduate thesis for the Department of Middle Eastern Studies at Ohio State University, Aseel Houmsse affirms the idea of the origin of Article 534 in the policies of the French Mandate: “Lebanon's current Penal Code contains many laws originally adopted from the French Mandate constitution. Among these is Article 534, located in Section II, which concerns the nations 'Promotion of Morality and Public Morals.' In keeping with the moral code left behind by the Mandate, this section outlines the 'appropriate' manner of social interaction in Lebanon. . . . Every unnatural act shall be punished by imprisonment for up to one year." ${ }_{3}$ Houmsse is quick, in effect, to cast this analysis in the tropes of a sinister Foucauldian Orientalist dynamic of discipline and punish at work against the hapless, passive Lebanese victims of French colonial designs. Therefore, Article 534, "was an attempt by France to regulate the social and cultural norms of the country in an effort to correct it, such that the more 'primitive' norms accepted by the Lebanese would be discouraged." ${ }_{4} 4$ And, further, "Though not directly implemented from Mandate laws, the idea of promoting 'morality' through the punishment of 'unnatural' acts such as homosexuality through the eyes of French Orientalism has had clear implications on modern Lebanese society." I5

Less frequently mooted, but significant in its own way, is the view that Article 534 is indeed a kind of "colonial relic" - but of the Vichy regime. On this view, Article 534 of Lebanon's Penal Code of 1943 reflects the newly promulgated Vichy law of August 6, I942, that allegedly criminalized same-sex relations. Writing about the history of HELEM, the Lebanese LGBTQ activist association, Ghassan Makarem lays responsibility for Article 534 squarely at the feet of the Vichy regime. Following rapidly in I943, Makarem claims, "Homosexual practices are criminalized in the Penal Code of Lebanon, under the moniker of 'unnatural sexual intercourse' . . s specifically sexual intercourse that includes anal penetration. It was derived from Vichy legislation during the so-called French mandate on Lebanon and goes against traditional Islamic interpretation of such practices." ${ }^{6}$ Makarem adds, "In order not to fall into contradiction with the Napoleonic Code, Lebanon criminalized homosexual acts with a punishment of imprisonment of up to one year. Expression of non-conforming gender identity is usually prosecuted under several other articles regulating public morality." ${ }^{17}$

Similarly writing on homosexuality in the Middle East, Serena Tolino claims Article 534 to be the result of changes to French law promulgated by the Vichy regime. This "changed art. 334 of the French Criminal Code and was then also adopted in Lebanon ... It was intended to protect the minors, but its application was then extended to all categories of 'unnatural' intercourse." ${ }^{8}$

Is Not a Crime, Says Lebanon's Top Military Prosecutor,” StepFeed, April I, 2019, https://stepfeed.com/ homosexuality-is-not-a-crime-says-lebanon-s-top-military-prosecutor-3 I 39.

I2 See, for example, Ghassan Moussawi, "Queering Beirut, the 'Paris of the Middle East': Fractal Orientalism and Essentialized Masculinities in Contemporary Gay Travelogues," Gender, Place, and Culture: A Journal of Feminist Geography 20, no. 7 (2013): 858-75, 868-70, and the sources cited therein.

I3 Aseel M. Houmsse, "Sociolinguistics of LGBTQ+ Discourse across Lebanese Law, NGO Policy, and Mass Media" (BA thesis, Ohio State University, 20I8), I5-I6, https://kb.osu.edu/bitstream/handle/I8I I/86886/ AHoumsseThesis.pdf? sequence $=\mathrm{I} \&$ risAllowed $=y$.

I4 Houmsse, "Sociolinguistics of LGBTQ+ Discourse across Lebanese Law," I 5-I6.

I 5 Houmsse, I6-I7.

i6 Makarem, "The Story of HELEM," 99.

I7 Makarem, 99.

I 8 Serena Tolino, "Homosexuality in the Middle East: An Analysis of Dominant and Competitive Discourses," Depertate, esuli profughe, no. 25 (2014): 72-9I, at 85, https://www.unive.it/media/allegato/dep/n25-20I4/ RICERCHE/o7_Tolino.pdf. 


\section{ARTICLE 534: COLONIAL RELIC OF NEITHER VICHY NOR THE MANDATE}

Such exclusively secularist claims of the French laïc colonial or Vichy provenance of Article 534 do not stand up to scrutiny. Take Vichy first. While the Vichy regime did tighten restrictions on samesex relations, Michael Sibalis notes, "homosexuality was never in and of itself a crime" - as the 2002 version of Article 534 did in Lebanon! In Vichy France, "the law penalized homosexual relations only between an adult and a minor under twenty-one." I9 To be precise, Pétain "amended Article 334 of the penal code" to condemn anyone who "to satisfy his own passions, commits one or several shameless or unnatural acts with a minor of his own sex under the age of twenty-one," ${ }^{20}$ The crime was actually that of corrupting or abusing a minor, not homosexuality or same-sex relations. Significantly, even "After the liberation of France, the provisional government under Charles de Gaulle, far from repealing Vichy's anti-homosexual legislation, issued an ordinance on 8 February I945 that reaffirmed it: "The principal motive of this [1942] reform, inspired by a concern to prevent the corruption of minors, cannot be criticized." ${ }^{21}$

Sibalis also goes on to argue that Pétain's law of August 6, I942, may actually have been provoked by concerns about maintaining discipline in the navy. On April I4, I942, the minister of the navy and commander in chief of French naval forces, Admiral François Darlan, wrote of his desire for the "repression of homosexuality." Darlan cited a vaguely described incident of "an important homosexual affair in which sailors and civilians have been compromised." Darlan declared, "I consider indispensable an energetic repression of this sort of affair, which risks doing serious moral damage to the navy." Petain's law of 6 August 1942 followed shortly thereafter. ${ }^{22}$ Still in all, Pétain's new law was, however, articulated in the tellingly theological terms of criminalizing "unnatural" acts, for reasons that may bear on Pétain's Catholicism, as I discuss below.

\section{WHAT OF THE OTTOMANS?}

If not a "colonial relic" of Vichy, is Article 534, perhaps, a relic of another colonial legacy? It is understandable that most readers will naturally assume that the Human Rights Watch's labeling Article 534 a "colonial relic" was intended to indict the French colonialism in the Levant. These charges are not altogether wrong. But they are imprecise to the point of virtual uselessness. For one, the French were not the only imperial power in Lebanon. The Ottoman Empire ruled Lebanon for some four hundred years. And even though the Mount Lebanon-based Maronites remained somewhat semi-autonomous throughout the Ottoman period, Ottoman power was a constant presence for centuries. So, while Article 534 may be a "colonial relic," perhaps it was an Ottoman rather than French "colonial relic."

Can a case be made for the Ottomans contributing to a moral-legal culture favoring the appearance of Article 534 in the mid-twentieth century? With Lebanon located where it is in the midst of the Muslim world, one is tempted immediately to imagine that even Christian Lebanese attitudes about subjects like homosexuality would resemble the Muslim. Legal scholars have indeed pointed out how the moral systems of Christians and Muslims tended to harmonize in places like

I9 Michael D. Sibalis, "Homophobia, Vichy France, and the 'Crime of Homosexuality': The Origins of the Ordinance of 6 August I942," GLQ: A Journal of Lesbian and Gay Studies 8, no. 3 (2002): 301-I8, at 302, https://muse.jhu.edu/article/I 22 I 5/pdf.

20 Quoted in Sibalis, "Homophobia, Vichy France," 30 I.

2 I Sibalis, 30 I.

22 Sibalis, 303 
Lebanon. ${ }^{23}$ Indeed, generally speaking, most schools of Muslim jurisprudence have viewed samesex relations as grave sins, typically meriting severe hudud penalties. Yet this picture of Muslim thinking regarding sexual morality grossly simplifies a complex situation. A considerable gap sometimes existed, for instance, between proscription and enforcement. As Haider Ala Hamoudi notes in a blog post, "Islamic law clearly proscribes fornication, and establishes for it a severe punishment (80 lashes for one who has never been married, stoning for one who has)." Yet since "four witnesses have to witness the act of sex itself," Hamoudi believes, the proscription against fornication (zina) is rarely enforced. The law may really be more symbolic than actual-just a "rather absolute statement about the deep abomination that nonmarital sex is." ${ }^{24}$

Another complicating factor is the complexity of Muslim jurisprudential thinking in Lebanon, which is chiefly Sunni. When it comes to the legal and moral status of same-sex relations (liwāt), for instance, the tendency of three of the four Sunni Muslim schools of jurisprudence-Hanbali, Maliki, Shafi-has been to condemn same-sex relations: "Men who willingly submit to be penetrated were viewed through the lens of affliction or disease of the anus. Since beardless youth had characteristics in common with females on account of not having facial hair, their penetration did not merit as strong a reaction as in the case of the penetration of adult men, which was viewed as a major perversion." 25

Significantly, the Hanbali, Maliki, and Shafi, however, condemn liwāt on the basis of analogy (qiyās) with fornication (zina). The Shi'a have their own divisions into jurisprudential schools. The need to appeal to analogy reflects the fact that often specific infractions are not literally spelled out in the shari'a, Qur'an, or hadiths. This is the case for same-sex relations. These three schools reason about liwāt in the following way by analogy. Zina merits severe hudud penalties because it is deemed so by the sources of Muslim law. Since liwāt is not expressly condemned in these primary sources, one is left to reason analogously by way of qiyas. Thus, since it is deemed that liwāt is analogous to zina, it likewise subject to hudud punishments. Incidentally, modern Muslim sexual morality reformers, however, take heart in pointing out that such conservative condemnation of gay sex does not rest on the strongest scriptural and legal support, but on qiyās. Reformers like Jahangir and Abdullatif, for instance, explain, "In essence, since the current neo-traditionalist Muslim position on same-sex unions does not stem from express texts but derived through analogy [qiyas], which yields probabilistic knowledge, and alleged consensus [ijma], which is contested, it facilitates revisiting and developing a renewed perspective on Muslim same-sex unions." 26

Now, since Muslim criminalization of same-sex relations depends on the employment of analogy (qiyās), this leaves the Hanafi school in a unique position. The Hanafis reject criminalizing same-sex relations (liwāt) and classifying liwāt as a major crime, because they reject the use of qiyās. ${ }^{27}$ Hanafi jurists refused to permit the use of analogy (qiyas) to extend the application of the severe textually

23 Chibli Mallat, "From Islamic to Middle Eastern Law: A Restatement of the Field (Part I)," American Journal of Comparative Law 5I, no. 4 (2003): 699-750, at 7I4.

24 Haider Ala Hamoudi, "Same Sex Relations and Islamic Law: Understanding Premodern Hanafi Jurists," muslimlawprof (blog), June 29, 20I 5, http://muslimlawprof.org/20I 5/06/same-sex-relations-and-islamic-law-understandingpremodern-hanafi-jurists/.

25 Junaid Jahangir and Hussein Abdullatif, “Same-Sex Unions in Islam,” Theology and Sexuality 24, no. 3 (2018): I $57-73$, at 160 .

26 Jahangir and Abdullatif, "Same-Sex Unions in Islam," I 59.

27 M. Alipour, "Essentialism and Islamic Theology of Homosexuality: A Critical Reflection on an Essentialist Epistemology toward Same-Sex Desires and Acts in Islam," Journal of Homosexuality 64, no. 6 (2017): 193042 , at 1937, I939n8. 
based hudud penalties because they felt doing so exceeded their right to read into the mind of Muhammed. Consequently, although same-sex relations (liwāt) remain sins, the Hanafis "did not believe there was any reliable authority pursuant to which the Prophet ever declared homosexual sex to be a crime worthy of punishment. A sin, yes, but a punishable crime, no." ${ }_{28}^{8}$ Analogical reasoning could not then be employed to extend to same-sex relations what belonged properly to, say, other sins of sexual misconduct, like fornication (zina).

Apart from such nuances of classic Muslim jurisprudence, beginning in I 839, Ottoman modernizing moves, such as the Tanzimat reforms, included the adoption of French civil and penal laws. Neither of these imported sets of laws-Napoleonic Code (I804) or French Penal Law (I8IO) -criminalized same-sex relations, either. Nothing in these European legal codes, therefore, gave evidence of a law cognate with Article 534.29 Beyond the prestige that French jurisprudence enjoyed, historian Mark Farha claims that the Muslims found it especially easy to adapt their own laws to the French. This congruence with French law further accounted for its rapid "spread throughout the Middle East." $3 \circ$ The ease with which the Ottomans embraced French Napoleonic Civil and Penal law, at least, raises the question whether we should focus on other sources of the kind of law Article 534 represents-arguably still of French provenance, but perhaps not secular and governmental?31

If Article 534 is a "colonial relic," the historical responsibility for its declaration of homosexuality as "unnatural" would seem, as Human Rights Watch suspects, to fall ultimately upon the French-even if which segment of French government and society remains to be determined. I have already put Vichy ordinances aside. Can the secular directorship of the French colonial adventure also be so easily and directly set aside?

A starting point can be found in the laws of the era of greatest French influence in the Middle East - the years dating from the mid-nineteenth century, the Second Empire, through to the Third Republic and the French Mandate (I920-I946).32 Above I assert that French law did not criminalize same-sex relations, but without close attention to that body of law. Below, to check for telltale traces of Article 534's language of same-sex acts as "contrary to nature" or "unnatural acts," I provide a precise consideration of what the Napoleonic Code or French Penal Code have to say about same-sex relations.

\section{“DOIN' WHAT COMES NATURALLY” IN FRENCH LEGAL AND POLITICAL THOUGHT}

At first, taking a French line of inquiry for evidence of Article 534's language of natural/unnatural seems particularly promising because at least since the Enlightenment, French legal and political thought presents a watershed of discourse about nature, natural law, and cognate notions. For example, the Napoleonic Code's concern with nature derives from its being largely an adaptation of another legal code likewise consumed with issues of nature-Emperor Justinian's sixth-century

28 Hamoudi, "Same Sex Relations and Islamic Law."

29 "Crimes and Delicts against Individuals: Attacks on Morals," in Penal Code of France (London: H. Butterworth, I8I9), 6I-95.

30 Mark Farha, "Stumbling Blocks to the Secularization of Personal Status Laws in the Lebanese Republic (I926-2013)," Arab Law Quarterly 29, no. I (2015): 3I-35, at 37.

3 I Hibaaq Osman, "Laws That Allow Rapists to Marry Their Victims Come from Colonialism, Not Islam," Independent, August 2, 2017, https://www.independent.co.uk/voices/rape-conviction-laws-marry-rapist-jordanegypt-morocco-tunisia-came-from-french-colonial-times-a7872556.html.

Human Rights Watch, "Lebanon: Same-Sex Relations Not Illegal.” 
Corpus Juris Civilis. Jean-Jacques Régis de Cambacérès, one of the principal authors of the Napoleonic Code, repeatedly notes that Justinian's Code recognized various species of law, such as "civil law," "law of nations," "scriptural law," and "natural law." During the course of his projects on Justinian's Code, he had occasion to say that "nature [had been] the only oracle that we would have consulted." ${ }_{3}$ In De Cambacérès's adaptations of Justinian, he used the word "nature" ninety-eight times. This included his arguments referring to "nature" (as in "natural law," for instance) ninety-three times, and an additional five times to show that the legal principles he was presenting originate in nature. 34 De Cambacérès eloquently reveals how much he valued "natural law": "the jurist recognizes that 'the civil laws [are] always faithful to the precepts of nature' and that 'there is a law superior to all others - eternal law, unalterable, common to all peoples, suitable in all climates - the law of nature. This is the code of all nations-one that the centuries have not been able to alter, nor have interpreters been able to distort. This, therefore, is what we ought to be consulting." "35

In addition to Justinian's Corpus, De Cambacérès also adapted John Locke's theory of natural law to much of Europe's new civil law, as had many of the Lumières. ${ }^{36}$ Thus, the legal thinking of the Enlightenment and French Revolution in Napoleonic civil law, at the very least, owes a great deal to Roman and Lockean doctrines about natural law.

What is not often recognized-but is critical to my arguments about Lebanon-is that Locke derived his notions of natural law from Thomas Aquinas, as mediated by a major Renaissance interpreter of Aquinas, Richard Hooker (I554-I600). In this line of influence, doubtless through Sir Edward Coke and Sir William Blackstone, are critical sources of the widespread legal claim that same-sex relations are "unnatural," as Article 534 asserts. ${ }^{37}$ Here, then, we might locate British colonial references to laws specifying "carnal intercourse against the order of Nature" ${ }^{8}$ or "carnal knowledge against the order of Nature." 39 Hooker stands as a major promoter of the cardinal place of "the natural" and natural law-although Thomas Hobbes cannot be excluded. This point is critical to my discussion below that Aquinas's theory of natural law passes to John Locke's, and from thence to Enlightenment and Revolutionary civil law's celebration of the natural, realized finally in De Cambacérès's monumental Napoleonic Code. Critically, that Thomistic legacy of legal history belongs equally well to the heritage of the modern Lebanese legal system as it does to Western Europe. $4^{\circ}$

\section{THE PENAL CODE, NOT THE CIVIL}

A careful reader might have noted some gaps in my line of reasoning. The Napoleonic Code (I 804 ) was a civil code, not a penal or criminal code, of which Article 534 is a part. Similarly, Lebanon's

33 Patrick Logoras-Flavigny, "Cambecérès et Locke," Annales historiques de la Révolution française, no. 307 (I997): I05-I 5, at I08, quoting Cambecérès ("nature [had been] the only oracle that we would have consulted). All translations of this source are mine.

34 Logoras-Flavigny, "Cambecérès et Locke," Io8ni7.

35 Logoras-Flavigny, I08, quoting Cambecérès (emphasis in source).

36 Logoras-Flavigny, I го.

37 Donald C. Knutson, "Introduction," Journal of Homosexuality 5, no. I/2 (I980): 5-23.

38 Act no. 45 of I860, Pen. Code $\$ 377$ (I 860) (India).

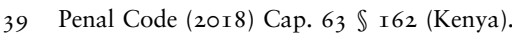

40 Eugeen De Jonghe, "Locke and Hooker on the Finding of the Law," Review of Metaphysics 42, no. 2 (I988): $30 \mathrm{I}-25$. 
Constitution of 1926 remains faithful to French models and does not concern itself with criminality, either. Remarkably, the French Penal Code of I 8 Io-which does, of course, treat crime-does not classify homosexual acts as crimes. The only portions of the Penal Code of I 8 Io dealing with sexual relations occur in Book 3, Title II, Chapter I, Section IV, Articles 33 I and 334. In effect, if homosexual acts are being criminalized in these articles, it is stated cryptically:

33 I. Who shall commit the crime of rape, or shall be guilty of any other attack upon the modesty, consummated or attempted, with violence, against an individual of either sex, shall be punished with solitary imprisonment.

...

334. Whoever shall have attacked morals, by exciting, favouring, or facilitating, habitually, debauchery or corruption in the youth of both sexes, under the age of twenty-one years, shall be punished with an imprisonment of from six months to two years, and a fine of from 50 to 500 francs. $^{4}$

By contrast, Article 534 of Lebanon's Penal Code of 1943 and its later revision do criminalize same-sex relations, however implicitly. The French Penal Code of I8 Io faithfully follows the Revolution's penal code of I79I: neither mention homosexual acts as either illegal or "unnatural." Although I have not been able to locate a French or English version of Lebanon's first penal code of the Mandate period (I926) to check whether "unnatural" acts are mentioned there, I assume, that since the early Mandate is at issue, the Lebanese penal code of 1926 may well have followed the French example of I 8 Io and simply remained silent about same-sex relations until it becamefor one reason or another-necessary to address this issue in I943. Why would we expect anything different from the Lebanese earlier in the twentieth century?

Having noted the French law's official statutory indifference to same-sex relations, I do, however, heed Sibalis's qualifications that the failure of the Penal Code of I 8 Io to criminalize homosexual acts did not decriminalize same-sex relations in practice-especially after the Bourbon Restoration (I 8 I4). Police and other local law enforcement authorities continued to harass homosexuals, routinely prosecuting them under other legal rubrics informally understood to target homosexuals. "Public indecency" was one such crime used as a pretense to penalize homosexuals. $4^{2}$ The Lebanese practice today also follows the example of the French in rationalizing persecuting of homosexuals under notions like legal proscriptions of public indecency, corrupting youth, and so on. There, "[t]he appeals court ruled that the penal code should be interpreted in accordance with 'common sense' and principles of social justice. It found that consensual sex between adults of the same sex cannot be considered 'unnatural' as long as it does not violate morality and ethics, for instance, 'when it is seen or heard by others, or performed in a public place, or involving a minor who must be protected." 43

Lebanese practice of harassing members of the LGBTQ community, at least, under the Penal Code of I943, also continues to follow the French here: "Lebanese police use the combination of Article 534 and complimentary Articles of the Penal Code (particularly Articles 5I8-522), as an excuse to arrest, detain and intrusively physically examine perceived members of the LGBT population." 44

\footnotetext{
4I "Crimes and Delicts against Individuals: Attacks on Morals," 67.

42 Michael D. Sibalis, “Napoleonic Code," glbtq, 20I 5, 2, http://www.glbtqarchive.com/ssh/napoleonic_code_S.pdf.

43 Human Rights Watch, "Lebanon: Same-Sex Relations Not Illegal.”

44 Australian Government Refugee Review Tribunal, "Country Advice: Lebanon, LBN 36885 " (Canberra: Government of Australia, 20I0), 3 (internal citation omitted), https://www.ecoi.net/en/file/local/II48882/ I930_I293464099_lbn36885.pdf.
} 
Despite such matters of practice, when it comes to earlier statutes where one might expect to find a "colonial relic" of the Mandate or Vichy in Lebanon, I come up empty. Unlike Article 534, the French penal codes, with the possible exception of Vichy's, do not mention the "unnatural," nor explicitly same-sex relations. So, the mysteries swirling about Article 534 remain. How a "colonial relic" and why the language of the "unnatural"?

\section{WHY THE LEBANESE CRIMINALIZED SAME-SEX RELATIONS: A HYPOTHESIS}

The problem, then, is that despite the great debt to the legal traditions of France, Lebanon's notorious Article 534 of its Penal Code (I943) does criminalize homosexual relations. This suggests that the Orientalist model of citing external sources of oppression might require considerable adjustment in the case of Lebanon and Article 534. This discrepancy between French and Lebanese law points then to a native Lebanese genesis of Article 534 since, "even now, French doctrine and jurisprudence are very often used and quoted by Lebanese judges and lawyers." 45 Commentators have remarked upon the ability of "foreign (clerical) authorities to exert binding jurisdiction on internal Lebanese affairs ... [by means of] papal encyclical, or fatwas . . which are officially recognized and fully binding by the Lebanese state." ${ }^{6} 6$ But instead of seeing only French colonial or imperial authority active here, Article 534's appearance suggests the possibility of "native" Lebanese agency in its promulgation in I943. To assume greater "indigenous" Lebanese responsibility for Article 534 would then confirm a view mooted by Mark Farha. Referring to the French Mandate's "repeated attempts . . . to introduce a unified secularized civil status code in Lebanon," he observes that all these efforts at imposing a classically laïc colonial legal regime on the Lebanese failed because they "were blocked by defensive alliances and remonstrations of the sectarian heads." 47

What are some other indications that would help build the case that specifically sectarian religious resistance to a unified secularized civil status code could eventuate in the promulgation of a law like Article 534? For instance, Catholics resisted "departure from official ecclesiastical dogma in matters of marriage and divorce." ${ }^{48}$ It would scarcely be surprising that in I943 Lebanese Catholics sought to inscribe condemnation of "nonheterosexuality" into the new Penal Code. Adding the intransigent Catholicism of Pétainist precedents in France from 1942 only increases this likelihood. Nor would one be surprised to find Lebanese Catholics prominent among those resisting liberalizing laws like Article 534's criminalization of same-sex relations. Farha consequently argues, for example, that sectarian power in independent Lebanon energized the resistance of religious communities to civil marriage in Lebanon: "The constitution [I926] equally obliges the state to surrender key jurisdiction in the realm of personal status laws and education to the countries eighteen confessions in their self-administered schools and institutions." 49 The concessions made by the 1926 constitution to sectarian religious autonomy gave religious communities immense power in matters of personal status laws, which, in turn, would include laws relating to same-sex relations such as Article 534 .

\footnotetext{
45 Warren G. Wickersham and Marwan M. Nsouli, "Legal System of Lebanon: Summary and Bibliography," International Lawyer 5, no. 2 (197I): 300-07, at 300.

46 Farha, "Stumbling Blocks," 37.

47 Farha, 37 (my emphasis).

48 Farha, 35 .

49 Farha, 32.
} 
LGBTQ activists have gone even further to accuse precisely the constitutionally mandated power-sharing sectarianism-religious confessionalism-for the suppression of nonheterosexuality..$^{\circ}$ Codified in today's Lebanese constitution, it effectively grants "religious conservatives the power to promote values and policies that demonize nonheterosexuality." ${ }_{5}$

Some LGBTQ activists interviewed by John Nagle in June 2015 spoke in one voice about the poisonous effects on their sexual liberties made possible by the religious sectarianism structurally fundamental to Lebanese constitutions since 1926. Said one activist, "It is nearly impossible to find a Lebanese leader, decision-maker, influencer, who cares in the slightest about their political future, to come out in favour of ending 534. Unfortunately, the religious establishments are all incredibly homophobic and their lopsided influence on the policymaking process seeps through the decision-making." ${ }_{52}$ Eventually, Nagle argues, "the consequence of devolving power to hardline ethnoreligious leaders is to legitimize the oppression of women and sexual minorities" even to the extent that some activists in Meem-a Lebanese women's LBGTQ rights group-believe that "the sect leaders overseeing the personal status laws 'want to purify the world of homosexuality." " 53

While my focus is on the Catholic agency behind Article 534, the Meem statement makes it clear that all of Lebanon's eighteen major religious communities practice a homophobic politics. Nagle reports that other Meem representatives affirmed that "it is worth noting that all of the ... sects, parties, and coalitions between them strongly condemn homosexuality and all . . . are very poor in addressing human rights issues, and women's rights in particular." ${ }_{54} \mathrm{He}$ argues further that the reason for this across-the-board sectarian homophobia in Lebanon is that "nonheterosexuality destabilizes and threatens the narrative of the ethnic nation." 55 By shifting notions of identity to such markers as sexual preference, sex, gender, and so on, the old order's verities are disturbed. A new homosexual marker of identity "challenges the fixed categories of national identity, and sexual minorities." ${ }^{6}$ It would threaten to "represent pollutants to the fictive kinship of the national family" based on vested sectarian religious divisions. ${ }^{57}$ Strong political opposition to nonheterosexual solidarity can be expected as long as it challenges this doggedly maintained religious and ethnic sectarianism - the very "foundation of politics" in modern Lebanon..$^{8}$

\section{ARTICLE 534: A PRODUCT OF JESUIT-MARONITE CROSS-CULTURAL COLLABORATION?}

I hope I have thus far cast sufficient doubt on the narrow Orientalist reading of Article 534 as an externally originated "relic" of secular French colonialism. But if it is not a "colonial relic" of the standard secular variety, how was Article 534 the product of other kinds of cultural and social

50 John Nagle, "Crafting Radical Opposition or Reproducing Homonormativity? Consociationalism and LGBT Rights Activism in Lebanon," Journal of Human Rights I7, no. I (2018): 75-88, at 78 .

5 I Nagle, "Crafting Radical Opposition?," 77.

52 Nagle, $84-85$.

53 Nagle, 78 .

54 Nagle, 85 .

55 Nagle, 77.

56 Nagle, 77.

57 Nagle, 77.

58 Nagle, 77, quoting Melanie Cammett, Compassionate Communalism: Welfare and Sectariamnism in Lebanon (Ithaca: Cornell University Press, 2014), 64. 
forces? Internal Lebanese "religious conservative" sectarians played a role. But who were they, exactly? And, how did they achieve their ends? By themselves, or alone? Answers to these questions lie, I argue, in trying to account for Article 534's distinctive language criminalizing same-sex relations as "contrary to nature."

Such language is telling for several reasons, but not the least because it does not reflect stateinitiated French colonialism-until Vichy, that is - an issue that will need to be addressed in light of my playing down of Vichy's role in creating Article 534. Michael Sibalis notes that Article 534's criminalization of same-sex relations was not justified by the usual appeal to protecting underage citizens. Performing "unnatural" sexual acts did, however, qualify one for punishment under Article 534. But how to explain this fixation on the "natural" and "unnatural"? As I note above, the Napoleonic Code elevates categories like "natural" or "unnatural" to the level of moral discourse. The problem is, however, that the Napoleonic Code does not concern itself with criminalization of "unnatural" homosexual acts or any other. It is, rather, the French Penal Code of I 8 Io that is concerned with criminality. But it too does not criminalize same-sex acts as "unnatural," either. How then can Article 534 be a "colonial relic" in Lebanon, if the colonizer in question-France-does not employ the legal language of "nature" in descriptions of same-sex acts in its penal laws-at least not until Vichy's law of August 6, I942?

This, therefore, is why I argue that calling Article 534 a "colonial relic" oversimplifies the dynamic relations of external and domestic factors in making modern Lebanese moral, religious, and political culture. If true, this means, we need to take seriously claims like those of M. S. Mohamed that laws in French colonies and mandates were sometimes the product of negotiation and mutual adjustments between colonial authorities and local forces: "the development of sexually restrictive laws in ... Beirut under colonial rule is arguably thought to have been done out of appeasement to nationalists and the more conservative elements of both societies ... These elements were not only fighting against European immorality, but against the idea of colonialism as a whole." 59

About the regulation of sexuality in mandate Lebanon, Mandour writes, "Article $534 \ldots$ reflects the religious norms and the moral value system prevailing in society which remains largely a traditional one premised on traditional gender roles and relations." 60 This means that while "sexuality in Lebanon is regulated through a large body of legal articles and laws that penetrate the whole legal system, inherited in its modern form from the French colonial era," local sources of law and morality contribute their own share, as well. ${ }^{61}$

In Lebanon, for the better part of its modern history, these "traditional gender roles and relations" point unambiguously to the pious Vatican-oriented Maronite community. Maronite "orthodoxy and unwavering devotion to Catholicism" vouched for their conservative "anti-Jacobin counterrevolutionary credentials." ${ }^{62}$ Sami Baroudi and Paul Tabar write, "As in every large organization, one cannot deny the presence of dissenting voices within the Maronite church. Nevertheless, these voices are too faint to enable one to speak of any resistance from the

59 M. S. Mohamed, "Sexuality, Development and Non-conforming Desire in the Arab World: The Case of Lebanon and Egypt," Evidence Report no. I 58 (Brighton: Institute of Development Studies, 201 5), https://opendocs.ids.ac. uk/opendocs/bitstream/handle/I 23456789/7 I I 5/ER I 5 8_SexualityDevelopmentandNon-conformingDesireinthe ArabWorldTheCaseofLebanonandEgypt.pdf.

60 Mandour, "Potential Change in Media Discourse," 6.

6I Mandour, 6.

62 Ussama Makdisi, The Culture of Sectarianism: Community, History, and Violence in Nineteenth-Century Ottoman Lebanon (Berkeley: University of California Press, 2000), 82. 
Maronite clergy to the positions adopted by the Patriarch and the Council of Maronite Bishops." ${ }_{3}$

These observations about Maronite conservatism (and, doubtless, ultramontanism) mean that, while Article 534 may indeed date from the French Mandate period or earlier in the Second Empire, it would be, at the very least, the product of an intricate interaction between the moral cultures of external and internal parties. I am indeed arguing that such cross-cultural collaboration resulted in Article 534. It faithfully reflects "clerical" and theological interaction inaugurated by the French Catholic missionary efforts into Maronite Lebanon, prominently featuring the Jesuits. ${ }^{64}$ As Chantal Verdeil says, "studying the history of the Catholic missions closely linked to France its government as well as its church," means, in effect, studying "the Jesuits of the Middle East in the period spanning the nineteenth century up until the Second World War." ${ }_{5}$

The Maronites welcomed foreign Jesuit theological influences in much the same way they welcomed French military and political protection for their community. In collaborating with the theological efforts of the Jesuits, the Maronites, in effect, "indigenized" them, making Jesuit spirituality and moral teaching something of their own. In effect, the Maronites may have created for themselves a hybrid culture that would have been more than capable of generating specific laws such as Article 534. After all, the language of "nature" and the "unnatural" permeated the Thomistic moral theology championed by the Jesuits. Both Jesuits and Lebanese thus, formed a common mind in their condemnation of same-sex relations as "unnatural." If Article 534 was a "relic," it was a "relic" of the thirteenth-century Thomistic moral theology taught to them by the Jesuits.

\section{AQUINAS ON “UNNATURAL” ACTS AS THE “THE GREATEST OF THE SINS OF LUST"}

In general, along with Plato, Sir Edward Coke, and Sir William Blackstone, Aquinas is among the critical sources of the widespread legal claim that same-sex relations are sinful because "unnatural." ${ }^{66}$ The locus classicus of Aquinas's arguments for his severe condemnation of homoeroticism as "unnatural" is to be found in Summa Theologica II, 2, Question I 54, Articles II and I2. In Article II, Aquinas tells us that the "unnatural vice" includes "copulation with an undue sex, male with male, or female with female, as the Apostle states (Romans I:27), and this is called the 'vice of sodomy,"” or, finally, "by not observing the natural manner of copulation, either as to undue means, or as to other monstrous and bestial manners of copulation." 67 In exchanges consisting in several anonymous "Objections" and Aquinas's "Replies to Objections" and "Sed Contras," Aquinas concludes by judging "the unnatural vice" of homoerotic relations specifically

63 Sami E. Baroudi and Paul Tabar, "Spiritual Authority versus Secular Authority: Relations between the Maronite Church and the State in Postwar Lebanin: I990-2005," Middle East Critique I8, no. 3 (2009): 195-230, at I96n5.

64 Serkan Gul, "The French Catholic Missionaries in Lebanon between I860 and I9I4” (PhD diss., Middle East Technical University, 20I 5), http://etd.lib.metu.edu.tr/upload/I 26I8780/index.pdf.

65 Chantal Verdeil, "The Jesuits and the Middle East from the Nineteenth Century to the Present Day: A Historiographical Essay,” in Jesuit Historiography Online, ed. Robert A. Maryks (Brill Online, last modified February 20I8), https://referenceworks.brillonline.com/entries/jesuit-historiography-online/the-jesuits-and-themiddle-east-from-the-nineteenth-century-to-the-present-day-a-historiographical-essay-COM_2056I7.

66 Knutson, "Introduction," 8.

67 Aquinas, II, 2, Question I 54, Articles I I and I 2, in The Summa Theologice of St. Thomas Aquinas, trans. Fathers of the English Dominican Province [2nd and rev. ed., I920], online ed., ed. Kevin Knight (n.p.: New Advent, 20I7), https://www.newadvent.org/summa/3 I 54 .htm. 
the "greatest sin among the species of lust." A measure of that gravity can be gauged by Aquinas's ranking same-sex relations - what he calls "the unnatural vice" - a vice graver than certain acts of cruelty, acts devoid of compassion and love, inflicting pitiless suffering, specifically, what he terms "adultery, seduction and rape." 68 Notably for a Christian, engaging in the "unnatural vice" of same-sex-relations far outranks sins contrary even to Christian charity-sins, such as "adultery, seduction and rape," causing grave injury and suffering.

But why does Aquinas rank same-sex relations as the "greatest of the sins of lust" (my emphasis)? Why the superlative? He answers simply: Same-sex relations offend against "nature." In offending "nature," same-sex acts offend nature's God. This alone is reason enough for Aquinas to lay down "the unnatural vice . . that very intercourse which should be between God and us is violated." And, why? The unnatural vice causes "that same nature, of which $\mathrm{He}$ is the Author . . . [to be] polluted." ${ }^{69}$ Communication between divinity and humanity is corrupted. Mark Jordan shows further how for Aquinas "the Sodomitic vice" is "horrifying and disgusting in a way that atrocities are. . . These acts are outside correction, and hence outside ethical discussion," and thus in an "unhuman beyond." 70

Faithful midwives of Thomistic moral theology, Jesuit missionary moral instruction about sexual morality in Lebanon would have aped this condemnation of same-sex relations. As for Article 534's condemnation of same-sex relations as "unnatural," we can see how Aquinas's condemnation of them as "the greatest of the sins of lust" - precisely because "unnatural" - might shed light on Article 534's identical language. I argue, however, that Article 534 should be seen as the product of collaboration. Below I discuss Maronite religious culture and theology prior to Jesuit influence to show how it might account for the receptiveness of the Maronites to Jesuit instruction against samesex relations.

\section{ADD THE MIDDLE EASTERN LEGAL KOINE, AND MIX}

An obvious reason for Maronite receptivity to Thomistic condemnation of same-sex relations may have been their own ancient theological traditions. If so, then that would offer another reason for seeing Article 534 as the product of the interaction of Jesuit missionary moral theology and the Middle Eastern moral and legal traditions of their Maronite students. After all, the territory consisting of today's Lebanon was the home of some of the most ancient schemes of law. Even though many legal systems proliferated across the entire Middle East, there were significant resemblances among them. Both the biblical and Quranic rule of an eye for eye, a tooth for a tooth are, for instance, calques of the Code of Hammurabi (I8IO-I750 BCE), numbers 96 and 200. But Hammurabi did not proscribe or even mention same-sex relations. ${ }^{71}$ And although Hammurabi did not proscribe same-sex acts, the slightly younger Assyrian Laws \#20 (I45-I250 BCE) seems so to do. The matter is not entirely clear, given that in \#20, it says, "If a seignior [an Assyrian man] lay with his neighbor [another citizen], when they have prosecuted him (and) convicted him [the first citizen], they shall lie with him (and) turn him <the perpetrator > into a

68 Aquinas, II, 2, Question I 54, Article I 2.

69 Aquinas, II, 2, Question I 54, Article I2 (quoting Augustine, Confessions, iii, 8).

70 Mark D. Jordan, The Invention of Sodomy in Christian Theology (Chicago: University of Chicago Press, I997), I 5 O.

7 I Mallat, "From Islamic to Middle Eastern Law," 702. 
eunuch." 72 Commentators have questioned whether only the compulsion of the act was condemned here, and not the act of penetration itself. One will note that only the penetrator is condemned to castration - not his target victim.

Taken as a whole, the resemblances between legal codes were often numerous and profound. They resulted in what Chibli Mallat refers to as a "deep Middle Eastern legal patrimony." 73 So substantial was the depth of the Middle Eastern legal patrimony, in particular, that some scholars posit that the "close resemblances in substance and form across religions and eras [argue in] favor of an identifiable, common Middle Eastern legal koine." 74 Given that two of the region's legal systemsboth the Syro-Roman law of Lebanon and Muslim law (also, arguably the Assyrian Laws and biblical, but not the Hanafi)-proscribed same-sex relations, it is plausible that an aspect of that "legal koine" was moral disapproval of same-sex unions.

In the case of Lebanon's part in the Middle Eastern legal koine, we must, therefore, consider local Lebanese legal traditions of criminalization of same-sex acts that had at least one foot in the period before the intense French political and religious penetration of the mid-nineteenth century. One such prominent code of the early modern era was established by the bishop of Beirut, Abdallah Qara'ali (I672-I742). His Mukhtasar al-shari'a (I720) was a compendium of law that until recently guided the Maronite community. In turn, it was also intensely faithful to the thirteenth-century, Ethiopian Coptic compendium of Ibn al-Assal, Fetha Nägäst, as it was with Muslim law dominating this part of the world.75 Beyond that, Mallat also claims that Qara'ali "incorporates verbatim passages from the sixth century CE Syro-Roman Code" found in al-Assal's Fetha Nägäst..$^{6}$ Here, we may pick up the thread of criminalizing same-sex behavior, since Syro-Roman law punishes homosexuality with death. 77 However, Syro-Roman law does not do so in the language of natural law and "unnatural acts." This discovery means that we now have evidence of pre-French Lebanese condemnation of same-sex acts in the Middle Eastern legal koine. With that discovery, we then can justify why the Maronites would have been receptive to the Catholic condemnations of same-sex relations, delivered by the nineteenth-century French Jesuit and Lazarite missionaries.

But the quest for the genealogy of the language of the "unnatural" applied to same-sex acts does not end there. Below I continue the investigation of the Jesuits and their Thomistic moral theology to show how they fit into the Vatican's missionary enterprises in the Middle East. In doing so, I expose Article 534's discourse of the "natural" and "unnatural" as a "relic" of the Vatican's missionary enterprises in the Middle East-of which the Jesuit missions formed an integral part.

\section{THE VATICAN DISTURBS THE PEACE IN THE LEVANT}

What do we know of the Vatican's conceptions of the Middle East and its plans for the missions to be sent there? To the Vatican, the Levant presented a confoundingly extravagant and ultimately

72 Bruce L. Gerig, "Homosexuality in the Ancient Near East, beyond Egypt," in Homosexuality and the Bible (2005), http://epistle.us/hbarticles/neareast.html (clarifications in parentheticals and brackets in the original; clarifications in angle brackets by author).

73 Chibli Mallat, Introduction to Middle Eastern Law (New York: Oxford University Press, 2007), 23.

74 Mallat, "From Islamic to Middle Eastern Law," 7I4.

75 Mallat, 7I4.

76 Mallat, 7I4.

77 Benjamin Z. Kedar, "On the Origins of the Earliest Laws of Frankish Jerusalem: The Canons of the Council of Nablus, I I20," Speculum 74, no. 2 (I999): 31 5-24. 
corrupt congeries of religious expressions - nonetheless at relative peace with each other. To its disappointment, the Vatican found in Lebanon communities of Christians, Sunni and Shi'a Muslims, Druze, Alawites, and others coexisting in the relative peace of a conviviendo. Not "finding the Catholics they had expected to find," the missionaries "were confronted with ... the confusing similarity of Christian to Muslim in manners, dress, and habits." ${ }_{78}^{8}$ As relatively undifferentiated entities within the broader embrace of the Ottoman Empire and its millet system of religious communal autonomy, these communities did not sharply distinguish themselves from their neighbors on religious grounds. 79

In terms of Lebanese confessional identity, this lack of sharp sectarian distinctions meant that designations of orthodoxy, whether in terms of "heresy or infidelity were assigned and revoked rather than permanently affixed." 80 What Ussama Makdisi calls the "contingent nature of public religious identity," prevailed in the Levant. ${ }^{8 \mathrm{I}}$ Religious identity was, then, more a matter of the employment of certain "tactical devices" of religious identity than an absolute expression of loyalty to a confessional affiliation. ${ }^{82}$

In terms of religious practice, these theological and sociological facts translated into common examples of a Christian-Druze-Muslim religious conviviendo, such as the sharing of a common place of religious devotion, even shrines to the Virgin Mary. In such practices, the missionaries saw only an intellectually indefensible muddying of the religious waters. What else but incoherent theological nonsense, the missionaries rhetorically asked, was a Shi'a emir's being buried in a Sunni cemetery, a Christian merchant's financing the construction of a mosque, a place where an emir could be Druze to the Druze, Christian to the Christians, and Muslim to the Muslims, or a Muslim notable's furnishing his palace with both mosque and church. ${ }^{8}{ }^{3}$ So depressed by the theological failure of Christian and Muslim sharply to distinguish themselves from one another that some nineteenth-century Christian observers even felt the Eastern "Christians here are so only in name." ${ }_{4}$ In the process, I do not mean to romanticize the Levantine conviviendo. Its theological roots may be shallow. But it did reflect a practical compromise providing for mutual acceptance and commitment among religious communities - so long as one community did not encroach on the "sacred territory" of another. ${ }^{85}$ As we will now see, for the Vatican and its Jesuit emissaries, such Christian-Muslim syncretism ran head on against their ultimate confessional goals of a Catholic Levant.

\section{SENDING IN THE JESUITS TO CREATE SECTARIANISM}

The Vatican responded to this situation of theological tolerance in the Levantine conviviendo by deliberately choosing Jesuit emissaries to attack and undermine it. Like their secular cousins of later centuries, Vatican authorities presumed that this peaceful Levant presented them with a "stagnant present, literally from the dearth of hope and the death of time." ${ }^{86}$ But thanks to the arrival of

78 Makdisi, The Culture of Sectarianism, 26-27.

79 See generally Makdisi, chapter 3.

80 Makdisi, 46.

8 I Makdisi, 46.

82 Makdisi, 46.

83 Makdisi, 35 .

84 Makdisi, 27.

85 Makdisi, 36 .

86 Makdisi, 20. 
Latin missionaries, the church hoped to make this dismal past evolve into "a future filled with promise and progress." 87 Dominating Vatican reactions to the Levantine conviviendo was the desire to secure a unique sense of Christian confessional or sectarian identity among the Maronites and simultaneously "préparer l'éventuelle conversion des musulmans." ${ }^{8}$ To accomplish these confessional objectives, the Vatican sent in the Jesuits to the Levant on a "projet ecclesial." 89 This commission concluded by creating, in effect, the kind of religious confessionalism or sectarianism characterizing religion in the post-Reformation Europe of the day. $9^{\circ}$ Originating as they had at a high-water mark in European "confessionalism," the Jesuits imagined a Lebanon of "pure Christian spaces," not what was to them, a wooly conviviendo typical of the Ottoman Levant.91 As Bernard Heyberger and Chantal Verdeil observe, "The diversity of religions and churches in the Orient did not [then] induce the Jesuit missionaries to see the Ottoman Empire as a model for religious tolerance. To the contrary, convivial community relations were perceived as a sign of overall religious degeneration that the Jesuits wanted to remedy." 92

The Jesuits sought above all to create in Lebanon the same kind of confessionalism or sectarianism they knew from Europe. In order then to "purify" their Maronite charges, the "Jesuit priests sheltered them [Maronites] from their indigenous surroundings" and they taught the Maronites both "to respect Catholic France and, implicitly, to disdain their immediate surroundings." 93 More than that even, the Jesuits sought to inculcate an "absolute expression of religious hostility" - which, in time, did successfully create a desired Maronite religious sectarian confessional identity. ${ }^{94}$ While the Muslims were the prime targets of this religious aggression, the Protestants were not far behind. During the tense decades of mid-nineteenth-century sectarian warfare, for instance, the need of Maronites to identify as Catholic was so extreme that any co-religionist who cooperated with the Protestants could be threatened with excommunication. ${ }^{95}$

In this way, Makdisi writes, "the arrival of missionaries . . sparked an indigenous concern for the preservation of Christian faith, for it was the missionaries, and not the Ottomans, who refused to accept the legitimacy of traditional Christian practice." ${ }^{6}$ In years to come, with the creation of a Lebanese nation-state and constitution, this sense of politico-religious sectarianism took the secularized form of the Lebanese political principle of communal "power-sharing." 97 "The upshot was that history, politics, and education - which in the old regime had reinforced a nonsectarian hierarchical social order-were all now put to work to create a sectarian hierarchal social order." ${ }^{8}$ The Jesuit missionaries came, then, to bring "not peace, but a sword" of sectarianism,

87 Makdisi, 20.

88 Sami Khuri, Une histoire du Liban à travers les archives des jésuites [A history of Lebanon from the archives of the Jesuits] (Beirut: Dar-el-Machreq, I991), 337.

89 Chantal Verdeil, “Travailler à la renaissance de l'Orient chrétien. Les missions latines en Syrie (I 830-I945)," Proche-Orient Chrétien 5I, no. 3/4 (200I): I-30, at IO.

90 Benjamin J. Kaplan, Divided by Faith: Religious Conflict and the Practice of Toleration in Early Modern Europe (Cambridge, MA: Harvard University Press, 2007), 28-47.

9I Makdisi, The Culture of Sectarianism, 9I.

92 Bernard Heyberger and Chantal Verdeil, "Spirituality and Scholarship: The Holy Land in Jesuit Eyes: Seventeenth To Nineteenth Centuries," in New Faith in Ancient Lands: Western Missions in the Middle East in the Nineteenth and Early Twentieth Centuries, ed. Heleen Murre-van den Berg (Leiden: Brill, 2007): I0-4I, at 38 .

93 Makdisi, The Culture of Sectarianism, 92.

94 Makdisi, 46.

95 Makdisi, I63.

96 Makdisi, 4I.

97 Nagle, "Crafting Radical Opposition?," 77

98 Makdisi, The Culture of Sectarianism, 8I. 
of confessionalism. In terms of the arguments made by LGBTQ activists of the role of sectarianism in the promulgation of Article 534, it should then be clear how the Jesuit sectarian initiatives contributed to such laws. The Jesuits "reflected, and gave credence to, a religiously segregated landscape" that the LGBTQ activists that I have cited believe eventually became the Lebanon that produced Article 534.99

The Jesuits first began missionary work in Lebanon as early as I 577 at the height of the rise of confessionalism in Europe. ${ }^{100}$ Although the Council of Florence had dispatched Franciscans to tend to the Maronites as early as 1450 , their presence was short-lived and gave way to the substantial subsequent presence the Jesuits were to have in the Levant. ${ }^{\text {IOI }}$ As early as I 596, Pope Clement VIII appointed the Thomist philosopher and theologian Hieronymus Dandinus (I 554-I634) as papal nuncio to Cyprus and Lebanon. Ever alert to doctrinal deviations, the Vatican tasked him to "report on the alleged errors and heresies of the Maronite Christians." ${ }^{102}$ His record of his visit and travels appeared as Missione apostolica al Patriarca e Maroniti del Monte Libano in I656. ${ }^{\mathrm{IO} 3}$ The Jesuit mission to Lebanon then began in earnest in I660. But by $\mathrm{I773}$, for reasons still not altogether understood, Pope Clement XIV suppressed the order worldwide. This resulted in the curtailment of Jesuit activities in Lebanon until they resumed in I83 I. And when the Jesuits returned to Lebanon, they were received with enthusiasm, as an American Jesuit reported at the time: "Indeed, no sooner had the knowledge of the restoration of the Society of Jesus reached Liban than a petition was sent from the residence of the Maronite Patriarch to Rome. This document, signed by four Oriental Patriarchs and five Bishops, begged Pius VII to send to the Eastern Church some of those evangelizers, whose confreres, still missed after forty years absence, had rendered such brilliant services to the East." ${ }^{\text {IO4 }}$

Upon their return, the first major act of Jesuit institution-building in Lebanon was the foundation in 1843 of a seminary in Ghazir, and later the foundation of Saint Joseph University in Beirut in 1875 . Their zeal in building the educational institutions in Lebanon that would secure Maronite sectarianism earned them an incomparable reputation-even among their competitors.

\section{A JESUIT EDUCATION FOR CONFESSIONAL PURITY AND MORAL RIGOR}

The Jesuit mission was tasked with the confessional and moral education of the Maronites. Although the Jesuits created a range of parochial educational institutions, they sought early influence in the formation of young Lebanese minds by their special attention to "local education." Iо5 Here, in the formation of Lebanese youth eager to assert themselves among nations, Jesuit education, in turn, formed Maronite communal self-respect and sectarian distinctiveness. At the height of the nineteenth-century French colonial period, the secular French governments even made the task

\footnotetext{
99 Makdisi, 9I.

Ioo Robert John Clines, "The Society of Jesus and the Early Modern Christian Orient," in Jesuit Historiography Online (Brill Online, last modified December 20I6), https://referenceworks.brillonline.com/entries/jesuit-historiography-online/the-society-of-jesus-and-the-early-modern-christian-orient-COM_I92582\#notesup42.

Iо I Makdisi, The Culture of Sectarianism, I83n46.

I02 Michael Edwards, “Digressing with Aristotle: Hieronymus Dandinus' 'De corpore animato' (I6IO) and the Expansion of Late Aristotelian Philosophy," Early Science and Medicine I3, no. 2 (2008): I27-70, at I35.

I03 Edwards, "Digressing with Aristotle," I 56.

I04 Louis Jalabert, “The Jesuit Mission in Syria: I83 I-I93 I,” Woodstock Letters, no. 6I (I932): 207-48, 375-406, at 2 I4, https://jesuitarchives.omeka.net/items/show/874.

I05 Makdisi, The Culture of Sectarianism, 89.
} 
of the Jesuits easier by entrusting the bulk of local education in Lebanon to the church's missionary congregations. Harry Paul notes that in Lebanon and Syria, "over 80,000 children were being educated by French citizens, seventy-five percent of whom were in religious orders." ${ }^{\circ 06}$ Thus, in Lebanon, the institutionalized laïcité of the government did not pit church against state as it did at home. In Lebanon, the state sponsored the efforts of the church, and in large part, the Jesuits role in education. ${ }^{107}$ As Chantal Verdeil writes, "With its network of schools, crowned by a prestigious university, whose main faculty (the medical faculty, opened in I 883) was generously funded by France, the mission of the Society in Syria appeared to be to act as one of the main vehicles of "French cultural interests in the declining Ottoman Empire." ${ }^{08}$ Ironically, the overall effect of the French state's handing over education in Lebanon to the church was to enhance confessionalism among the Maronites.

What strategy did the Jesuits follow in fulfilling their state-sponsored role in education? From the beginning, the Jesuits wanted to achieve two aims in their mission to the Maronites-one intellectual and the other practical. First, the Maronites needed to counter the ideology and practice of religious tolerance represented by the Ottoman religious conviviendo. The Jesuits felt that Maronite Christians had, in effect, been left theologically unequipped to counter the errors implicit in this condition of religious tolerance, thus making them easy prey to a loss of faith, schism, or heresy. ${ }^{\text {I09 }}$ The Jesuits were in Lebanon to repair the damage caused by Ottoman religious tolerance. Intellectually rigorous theological training in a sharply sectarian polemics would undo some of that damage. In effect, the Jesuits felt that the Maronites needed to be brought up to speed with the latest in "confessional" sectarian polemics honed from the time of their founding in the Counter-Reformation. ${ }^{\text {I }}$ Among the Maronites, the Jesuits hoped thereby to create nothing short of "pure Christian spaces ... indispensable for reform" - that is to say, a fully sectarian or confessional Maronite Catholicism. ${ }^{\text {II I }}$

The second aim of the Jesuit educational mission was wholesale moral regeneration of the Maronite community. In the eyes of the Jesuits, centuries under the Ottoman 'yoke' had made it difficult for Christians successfully to combat morally dubious Muslim influence. An I8 3 I letter from the Italian Jesuit Paul Riccadonna records his panicked disgust at the moral corruption, tied to theological illiteracy, in the Levant-a place where, as he puts it, "The Christians here are so only in name. And, now to this are added the Egyptians, the emissaries of Satan, the liberals, the carbonari, the biblists, the Methodists, the saint-simonians, sodomites and others, and all have the liberty to proselytize. Ob Lord! What woe! What horror!" II2

To overcome the corrosive effects of Muslim moral influence, the Jesuits sought to inculcate the essentials of Jesuit spirituality and virtue, prominently represented by Jesuit founder Ignatius Loyola's Spiritual Exercises and classic Catholic moral theology taught by the likes of Thomas Aquinas.

Io6 Harry W. Paul, The Second Ralliement: The Rapprochement between the Church and State in France in the Twentieth Century (Washington, DC: Catholic University of America Press, I967), 45.

I07 Paul, The Second Ralliement, 44-45; E. H. Ngwa Nfobin, "Homosexuality in Cameroon," International Journal on Minority and Group Rights 2I, no. I (2014): 72-130.

Io8 Verdeil, "The Jesuits and the Middle East."

I09 Verdeil, “Travailler à la renaissance de l'Orient chrétien,” Io.

I Io Kaplan, Divided by Faith, 27-48.

I I Makdisi, The Culture of Sectarianism, 9I.

I 2 Makdisi, 27, referring to citation of Paul Riccadonna, Letter to colleagues in the Roman College (Dayr al-Qamar, November 29, I83I) in Michel Jullien, La Nouvelle mission de la Compagnie de Jésus en Syrie I83I-I 895, vol. I (Tours: A. Mame et fils, I 898), 82. 
The Jesuits also deployed a program of moral reform relying on the systematic methods of education they had famously developed across Europe. These methods and regulations are embodied in the Ratio Studiorum, a compendium of the collective wisdom of teams of Jesuit educators working in collaboration to produce a portable vision of what a Jesuit education should be. For instance, the Ratio committed the Jesuits to what were to become some of the Renaissance's major contributions to humanistic education. Here, I single out the study of ancient classical languages and literatures, philosophy, and theology.

One should not imagine, however, that these studies were undertaken in an ethical and confessional vacuum. Rather, they were typically occasions for moral and religious formation. A Jesuit student might, for example, find their days filled with lessons in the Western classics in Greek and Latin, and in Lebanon, also Syriac, French, and Arabic. But the Jesuits could not help bending linguistic studies to the needs of theological indoctrination and moral instruction. Chantal Verdeil reports they did this very thing in Lebanon: "La religion, en particulier le catholicisme, marque aussi l'enseignement et la pédagogie. Les jésuites utilisent la grammaire de l'abbé L'Homond (I727-I794) dont les exemples servent à inculquer des valeurs morales: on y apprend les compléments avec des phrases comme 'j'aime Dieu' ou ‘je donne aux pauvres." II

Again, in the spirit of Renaissance humanism, the Jesuits also became well known in Lebanon for their promotion of the dramatic arts-but again, like stereotypical Jesuits, this promotion was for the purposes of doctrinal and moral formation. Through the heroes, martyrs (sometimes saints), kings, or knights portrayed in student theatricals, the Jesuits promoted loyalty to the church, obedience to the pope, and, more generally, submission to the clergy. Committed as the order was to an essentially confessional educational project, at the end of the Ottoman period, an analysis of the prestigious theater productions at Saint Joseph University concluded that the Jesuit theatricals had, in effect, presented their university as a sectarian island of Christianity.

Given Jesuit strategies of confessional education, one should resist separating the individual and social aims of Jesuit education from one another. In the Lebanese mission field, the Jesuits interpreted what they perceived as moral laxity of the Maronites as a direct consequence of their weak confessional doctrinal formation. The Jesuits, therefore, concluded that the way to attack the one was to attack the other, and vice versa. Theological rigor would bring greater care to morality. Moral regeneration would likewise comport with a disciplined confessional outlook. From their "enclaves of 'pure' Occidental Christianity, the Jesuits would penetrate the home and family," and thus, everyday Lebanese morality, including sexual morality. ${ }^{\mathrm{II} 4}$ Thus, the Jesuits convinced themselves that intensifying Maronite sectarianism went hand in hand with remedying the social and individual moral degeneracy they saw everywhere in Lebanon. This strategy shows how the Jesuits conceived their task in holistic terms, taking in the entire culture and the individuals making it up at one go. It is small wonder, then, that the Jesuits can be regarded as having had such a momentous impact on the emergence of a modern, sectarian Maronite moral mentality. The creation of the kind of moral culture promoted by the Jesuits, I argue, is a major ingredient in the creation of a moral culture that would produce laws like Article 534.

I 3 Chantal Verdeil, "Un établissement catholique dans la société pluriconfessionnelle de la fin de l'Empire ottoman: L'université Saint-Joseph de Beyrouth" [A parochial Catholic institution in a multi-confessional society at the end of the Ottoman Empire: Saint Joseph University, Beirut] Cahiers de la Méditerranée, no. 75 (2007): 28-38, at 3 I. "Religion, specifically, Catholicism also underscores teaching and pedagogy. The Jesuits use Abbé Homond's (I727-I794) grammar exercises to inculcate moral values: one learns about objective case, for instance, with phrases such as 'I love God' or 'I give to the poor.'” (My translation.) 


\section{FAMILY VALUES, SEXUAL SCRUPLES, AND JESUIT MORAL REFORM IN LEBANON}

How a few Jesuit missionaries could transform a whole culture, sufficient, say, to inform its legal and political systems is a remarkable story, and one in which sexual morality plays a key role. What had then begun as a religious missionary enterprise focusing on individual moral restraint became nothing short of a plan for "the transformation of local societies," II5 a total remaking of Lebanese society. No longer were the Jesuits content to educate "a few Lebanese in the Maronite College in Rome." The order had grand ambitions: "The purpose of the College had been largely achieved: it had successfully 'reformed' the Maronite Church and had Latinized it to a large degree. In the nineteenth century, the Jesuits' goal was far more ambitious and far more complex, for they aimed to 'regenerate' an entire population.”

This ambition for total societal regeneration gave rise to a campaign the Jesuits called a program to "make society moral" (moraliser la société). ${ }^{117}$ This slogan literally means the inculcation of "clean," or more felicitously, "wholesome" values (saines valeurs). If one were to permit taking some liberties with the literal meaning of moraliser la société, the familiar American expression family values might even convey the meaning of the French best.

But as evidenced by the hysterical expressions of horror at the societal conditions in Lebanon from Jesuit travelers like Riccadonna, the Jesuits felt they faced a daunting task before they could successfully moraliser la société. How to go about this monumental chore? Where should one start? The Jesuits answered in terms suggested by the founding spirit of Ignatius Loyola's Spiritual Exercises. Its methodically plotted program of moral formation informed by moral theologies ranging from Aquinas to the reforms of the Council of Trent provided a powerful theoretical basis for the moral revolution the Jesuits had in mind. ${ }^{\text {I } 8}$

This methodical approach to social regeneration begins with individual moral regeneration and piety-first among women, then men. In focusing first on women, Jesuit emphasis on moral instruction targeted the cardinal role of women in creating a morally wholesome Christian family lifeembodying the very notion of family values I use above to translate the French moraliser la société. Therefore, if one could moraliser women, one would, effectively, moraliser the family. Do that and total social regeneration was within reach, the Jesuits reasoned.

Why not begin with men morally to reform the family? Jesuit thinking argued that, while one might revolutionize society by training young men, if one wanted to establish a profound moral order in the family, one needed to enlist women in that effort. Once the family had been moralized, reforming society would follow of its own accord. Since women were the heart of the home life and thus the first teachers of the young, they - not men - held the key to establishing the "family values" the Jesuits prized as necessary steps on the way to total social reform. "Des congrégations féminines des auxiliaires" (women's orders of auxiliaries), therefore, were "indispensable" agents in securing a moral social order. ${ }^{19}$ Notably, in the mission field, Jesuit-affiliated female religious orders, chiefly the Sisters of Charity, worked alongside the Jesuit priests. (Below I discuss how Jesuit-formed Maronite leaders such as Patriarch Elias Peter Howayek (I843-I93I) paid the same focused attention on the cardinal role of women in securing the kind of modern, morally regenerated Maronite community he and other Maronite nationalists sought.)

\footnotetext{
I 5 Verdeil, "The Jesuits and the Middle East."

I 6 Makdisi, The Culture of Sectarianism, 89.

I 7 Verdeil, “Travailler à la renaissance de l'Orient chrétien," 23.

I 8 Pierre Hurteau, "Catholic Moral Discourse on Male Sodomy and Masturbation in the Seventeenth and Eighteenth Centuries," Journal of the History of Sexuality 4, no. I (I993): I-26.

II9

Verdeil, "Travailler à la renaissance," 290.
} 
What then of men? We know the Jesuits believed that men were equipped with the virtues necessary to bring about social revolution in Lebanon. Did those masculine virtues pair with corresponding vices? If so, what were these male moral vulnerabilities, and how ought one deal with them? Heirs to traditions of sixteenth-century Thomist and post-Tridentine puritanical suspicions about male temptations to sexual excess, the Jesuits saw sexual sobriety among men as critical. Indeed, male sexual restraint became for them a token of a new modern morality. The reasons behind this thinking are complex and not entirely understood. But in part, they arose from a particular terror of sexual deviance among men, noted by pious authors of this time. It attained such levels of excited concern that this conviction spawned an entire literature of moral casuistry about sexual deviance. Sexual discipline thus entered into the very conception of the ideal Catholic masculinity dominating the post-Tridentine thinking in which the Jesuits partook. Pierre Hurteau thus argues that the "regulation of 'deviant' male sexuality not only reached far beyond religious concerns about procreative sex but also developed as an integral part of men's understanding of their capacity to master social institutions rationally and subjugate the natural world to the power of dispassionate objective reason." ${ }^{20}$ One could go even further and concur with Hurteau that sexual restraint and self-scrutiny were coming to characterize the cardinal virtues of an emergent modern masculinity. The post-Tridentine church seemed to think so.

The Jesuits also advocated the cultivation of the habits of sexual discipline. Hurteau, for instance, argues that Ignatius Loyola's Spiritual Exercises promoted a scrupulous practical spirituality of introspection - the "frequent examinations of one's conscience" - that equipped the faithful

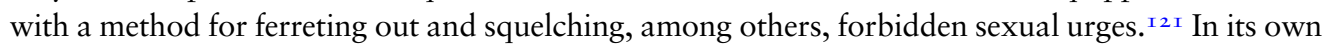
way, the rigorous introspection of the Spiritual Exercises became a new model for a type of introspective European man. As Avery Dulles observes, "In the areas of moral and pastoral theology Jesuits provided a theoretical and practical framework appropriate for the post-Tridentine era. In an age of absolutism, their respect for conscience and their advocacy of natural rights contributed significantly to the growth of political philosophy and jurisprudence." ${ }^{22}$ Here, the new post-Tridentine culture of sexual discipline became pivotal. "My contention," continues Hurteau, "here is that this new style of casuistry in sexual matters reflected important social

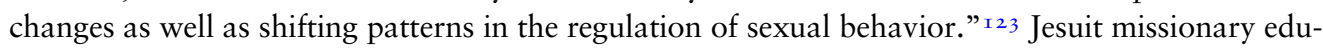
cation, says Makdisi, thus brought a "spiritual and temporal modernization," which would, ironically, prove to be "one and the same thing." ${ }^{224}$ A new moral theology and spiritual discipline eventuates in the creation of a new kind of Maronite man, capable of acting in and revolutionizing his own society along Catholic lines.

The path forward, then, as charted by the Counter-Reformation and its Jesuit legions, was not the easygoing hedonism of a Prince Hal and Falstaff, but a disciplined regime of serious intent and purpose of an introspective King Henry V. In this spirit, in Lebanon, from the middle of the nineteenth century, at the height of Jesuit missionary activity, teaching sexual and other discipline topped the agenda of individual, and consequently social, moral reform. In Lebanon, the Jesuits felt the key to their program of societal moral reform was intensifying a sense of individual

\footnotetext{
I 20 Hurteau, "Catholic Moral Discourse," 2.

I2I Hurteau, 6. Ignatius Loyola, The Spiritual Exercises of St. Ignatius of Loyola, trans. Elder Mullan (New York: P. J. Kennedy and Sons, I9I4).

I 22 Avrey Dulles, "Jesuits and Theology: Yesterday and Today," Theological Studies 52, no. 3 (I99I): 524-38, at 529.

I 23 Hurteau, "Catholic Moral Discourse," 4.

I24 Makdisi, The Culture of Sectarianism, 89.
} 
moral restraint. Being disciplined in moral matters and responsible to one's specially cultivated conscience and moral bearings fit the Jesuit model of what a modern Lebanese masculinity demanded. ${ }^{\mathrm{I} 25}$

\section{MARONITES AND JESUITS: “A TWO-WAY EXCHANGE - A CULTURAL COLLABORATION"}

The Jesuit missionaries, then, "were at the vanguard of a cultural movement that allowed for a twoway exchange-a cultural collaboration between Maronites and French Catholics of which the Jesuits were exemplars. The Jesuits provided the [Maronite] elites with seemingly viable and modern sectarian paths of development." ${ }^{26}$ Jesuit plans for their regeneration of Lebanese society thus played well to the Maronites. Their leadership, like Bishop Nicholas Murad, made no secret of their eagerness to collaborate with Catholic Europe-in effect, to argue "the case for a Maronite-dominated Christian Lebanon." I27 In his Notice historique sur l'origine de la nation Maronite et sur ses rapports avec la France (I844), Bishop Nicholas Murad said that the Maronites wanted nothing better than to secure its nationhood and "to take its rightful place alongside the European Christian states." ${ }^{228}$ To him, in effect, Maronite Lebanon was, in a way, already European in essence. Murad's idea of a Lebanon resulting in a fusion of modern "European nationalist idea with a tradition of Maronite ecclesiastical autonomy" ${ }^{\text {I29 }}$ spoke to the collaborative nature of the Maronite-French Catholic identity that had been formed by Jesuit missionary activity. ${ }^{130}$

It is critical to note that the Jesuit-Maronite collaboration resists the standard tendencies of the narrative of postcolonial theory - agent European colonizer imposing its will unilaterally on a passive, victimized colonial. In Lebanon, the Jesuits and Maronites seem genuinely to have collaborated, as Makdisi notes: "it is imperative to dispel any illusion that sectarianism is simply or exclusively a native malignancy or a foreign conspiracy. Sectarianism can be narrated only by continually acknowledging and referring to both indigenous and imperial histories, which interactedboth collided and collaborated - to produce a new historical imagination.” ${ }^{\mathrm{I} 3 \mathrm{I}}$

Makdisi's view is less surprising in light of observations about the way the Maronites had already been developing theories of their ethno-national dignity and uniqueness before the middle of the nineteenth century. In an I 840 request, a Maronite delegation to the Austrian court "insisted upon being treated" "without being mixed with any other sect." ${ }_{32}$ Four years later, in his Notice historique sur l'origine de la nation Maronite, Bishop Murad argued to Louis-Philippe that a close racial-ethnic examination of the Maronites would show how much they shared with the French.

\footnotetext{
I 25 Hurteau, "Catholic Moral Discourse," 25-26.

I26 Makdisi, The Culture of Sectarianism, 88.

127 Makdisi, 82.

I28 Makdisi, 82, citing Nicholas Murad, Notice historique sur l'origine de la nation Maronite et sur ses rapports avec la France, sur la nation Druze et sur la diverses populationsm du Mont Liban (Paris: Cariscript, I988), 27.

I29 Makdisi, 82.

I30 Makdisi, 89. The Jesuit plan was not, however, that the Lebanese would then flood into Europe. Instead, they "would be content with life in the Orient." Makdisi, 89.

I3 I Makdisi, 2.

I32 Makdisi, 6I, citing Richard Wood Papers, Box 2, File 3, Middle East Centre, Oxford University.
} 
Incredibly, Murad asserted that the Maronites were not just "pro-French," but were "actually French people" ${ }^{133}$ somehow misplaced by history in the Levant.

This Jesuit-Maronite collaboration in the creation of Maronite sectarianism tends to give credence to the view of recent LBGTQ commentators that Lebanese sectarianism facilitated the appearance of Article 534. It did so, because, as Nagle, Meem, and others argue, sectarianism entails "devolving power to hardline ethnoreligious leaders," ${ }^{5} 34$ suspected of bearing ultimate responsibility for Article 534. In thus accumulating such power by way of sectarianism, Lebanon's Latinized, conservative, Jesuit-educated, religious forces have been able so "to legitimize the oppression of women and sexual minorities." 135 Some Meem activists think that this desire to oppress goes so far that "the sect leaders"-including non-Catholics - "overseeing the personal status laws "want to purify the world of homosexuality." ${ }^{3} 36$ Article 534 looks a lot like something that would advance such a Lebanese sectarian homophobic agenda, even if all sectarian elements in Lebanon seem to share homophobia with the Maronites, if LGBTQ activists are to be believed. ${ }^{\mathrm{I} 37}$

\section{PATRIARCH HOWAYEK, PERFECTION OF THE MARONITE-JESUIT COLLABORATION}

The pivotal Maronite figure Patriarch Elias Peter Howayek illustrates how the Jesuit and Maronite collaborative vision was realized in Lebanon. ${ }^{1{ }^{8} 8}$ Although he is often credited with being the veritable founder of the modern Lebanese state, Howayek is more accurately seen as a fiercely Lebanese Maronite Catholic denominational sectarian. A leader of political agitation for an independent Lebanon, Howayek also was the seventy-second Maronite patriarch of Antioch. In the early twentieth century, for instance, Howayek affirmed Maronite Christian sectarianism politically in his nationalist desire for a "Petit Liban"-a Lebanon that-again - "should remain a Christian country, not a country with Christians living in it.” 139 On September I, I920, the Mandate's high commissioner, General Henri Gouraud, however, proclaimed the birth of Greater Lebanon ("Grand Liban"). But even as late as I923, Maronite sectarian nationalist elites such as Howayek preferred the "Petit Liban" dominated by the Maronites. Howayek grew accordingly ever suspicious of French plans for this Greater Lebanon because it would dilute Maronite

I33 Makdisi, 83, citing Murad, Notice historique, 46-48. Yet, despite Maronite eagerness to collaborate, the French did not always appreciate Maronite contributions to the hybrid culture being built by Maronite-Jesuit engagement. Voicing essentially racist suspicions of how thorough this collaboration could be, nineteenth-century traveler and poet Alphonse de Lamartine reported in his Voyage en Orient, "The Maronite people, be they descended from Arabs or Syrians, share all the virtues of their clergy, and constitute a people distinct from all others in the Orient, one might say a European colony haphazardly cast into the midst of desert tribes. Their personal appearance, however, is Arab." Makdisi, 22, quoting Alphonse de Lamartine, Voyage en Orient. 2 vols. (Paris: Hachette, I 875), I:405. Perhaps it was such suspicions that lay behind the Vatican view that Jesuit missionary activity should not cease until they had completed what amounted to a thorough Latinizing and reconversion of the Maronites into properly orthodox and orthoprax (Latin) Christians. This was no less than the Christianity then being fostered by the Jesuits according to the post-Tridentine, Counterreformation values prevailing in the Second Empire and beyond.

I34 Nagle, "Crafting Radical Opposition?," 78.

I 35 Nagle, 78 .

I36 Nagle, 78 .

I37 Nagle, 85 .

I 38 I note several variant spellings: Hoyek, Hoayek, Hwayek, Huayek, Hawayek, Huwayyuk.

I39 Abisaab Malek, "Warmed or Burnt by Fire? The Lebanese Maronite Church Navigates French Colonial Policies, I935," Arab Studies Quarterly 36, no. 4 (2014): 292-3I2, at 295. 
power by including in its large populations of non-Catholics. The lä̈c Mandate authorities thus revealed themselves as determined to thwart these long-standing Maronite ambitions for a Christian Lebanon. Once French plans to secularize Greater Lebanon became clearer, Howayek seized the occasion to deliver a sharp sectarian rebuke to Gouraud, expressing "his outrage at Gouraud's alleged preference for a federation joining Syria and Lebanon," and he "threatened rebellion if the French were to pursue this plan." ${ }_{40}$ This sense of privileged ownership enjoyed by Maronite elites of the new nation-state, dating from the earlier purely Maronite administrative authority of I 864 to I9I 8 -mutasarrifiyya-has never quite died out among the Maronites. ${ }^{\text {I4I }}$

Together with his Maronite sectarian-nationalist commitments, Howayek should also be seen as the perfect expression of Jesuit missionary success in Lebanon. He was, in a way, a model of the new Lebanese man created by the collaboration of the Maronite cultural legacy and the rigors of Jesuit theological and moral education. Howayek's links with the Jesuit Thomistic theology began at the tender age of sixteen or so, in I 859, when he first would have formally encountered Thomist theology at the Jesuit seminary in Ghazir, where he studied classic languages and philosophy. ${ }^{\mathrm{I} 2}$ Jesuit Thomistic intellectual formation shaped much of Howayek's outlook on morality and society into his maturity, as it did for many Maronite elites. Chantal Verdeil notes that Charles Frazee called attention to the Jesuit foundation, Saint Joseph University in Beirut, for its seminary and faculty of theology because it "provided Maronite and other Catholic Churches of the East with opportunities never before available." ${ }^{\text {43 } 3}$

Howayek's orientation toward the Jesuits also accounts for the subsequent importance of Catholic, principally Thomistic, theology in Maronite Lebanon. Howayek's sponsorship of the Jesuits and with them, Aquinas, had been sealed upon taking his doctorate in theology in Rome at the Sacred Congregation for the Propagation of the Faith in 1865 , then in the midst of a revival of Thomistic theology. While in Rome, Howayek would, for example, often meet frequently with Pope Leo XIII, leader of the church's resuscitation Thomism as its official theology. ${ }^{144}$

While in Rome, in 1894 Howayek also became acquainted with the ancient Levantine manuscripts once held by the Maronite College (founded by Pope Gregory XII in I 584). Ever the nationalist, and try though he might, Howayek was unable to get these Lebanese antiquities returned to the Maronite College as promised by Pope Leo. Howayek, nevertheless, benefited a great deal by the intellectual environment created by Leo and the Jesuits in the middle of the nineteenth century. Perhaps foremost of the intellectual treasures that fell into Howayek's lap were the newly revived theological works of Thomas Aquinas. In the footsteps of Aquinas himself, Howayek taught moral theology at the Seminary of St. John Maroun for many years. ${ }^{\mathrm{I} 45}$

Witness to Howayek's loyalty both to the Jesuits and to Thomism, once Howayek had gained sufficient ecclesiastical authority in Lebanon, he straightaway invited the Jesuits and other Latin religious congregations, such as the Lazarites - a Thomistically influenced missionary order - to set up schools in Lebanon. ${ }^{146}$ Upon returning to Lebanon, Howayek also founded the kinds of religious movements reinforcing "family values" and traditional sex roles, such as those-like the

I40 Malek, "Warmed or Burnt by Fire?," 295.

I4 I Malek, 293.

I42 Margaret Ghosn, The Charisma of Patriarch Elias Howayek (I843-I93I), 9, http://saintefamille.org/wp-content/ uploads/2018/og/charisma-book-new.pdf.

I43 Verdeil, "The Jesuits and the Middle East," n33. Charles A. Frazee, Catholics and Sultans: The Church and the Ottoman Empire, I453-I924 (Cambridge: Cambridge University Press, I983), 282.

I44 Ghosn, The Charisma of Patriarch Elias Howayek, I4.

I45 Ghosn, Io.

I46 Ghosn, 9. 
Jesuits - of the traditional heterosexual family. One such organization was, in fact, dedicated explicitly to devotion to the Holy Family. Quite possibly also indebted to Lazarite devotion to the Holy Family, Howayek sponsored the education of girls and women to assume their traditional roles of maintaining model Christian families.

So, with Howayek's Thomistic nurture, devotion to "family values," added to nineteenthcentury French Catholicism's antagonism to same-sex relations, Lebanese Maronite Catholics were well positioned to steer the Lebanese Penal Code toward an Article 534. How else to explain the Thomistic language of Article 534's formulation proscribing same-sex relations as "unnatural acts"? In Lebanon, the French Thomistic condemnation of same-sex relations would have found ready calques in Maronite Christianity's conservative theology of sexual relations, reinforced by Jesuit teaching or not: "To start with," say Baroudi and Tabar, "the Maronite Church is even more socially conservative than the mother Catholic Church; it opposes divorce, civil marriage, out-of-wedlock relationships and homosexuality." ${ }_{447}$ This is all to say that if the Lebanese Penal Code can be said to be a "colonial relic," it is a "relic" of a fundamentally clerico-theological collaborative enterprise, made possible by the surrender of French colonial influence in matters of moral education to the Jesuits and Lazarites, but nonetheless embedded in Thomistic moral theology and Middle Eastern legal koine supplied by the Maronites. Some commentators have even argued that Article 534's continued application and favorable judicial rulings actively conform to such native Lebanese preferences, rather than just passively reflect imposed colonial ones. There, native preference is alive, for "personal status laws continue to be regulated by the traditional laws inscribed in the respective religious codices of each of the country's denominations." I48

\section{ARTICLE 534: A COLLABORATIVE EFFORT OF LEBANON'S MARONITE-JESUIT MORAL CULTURE}

In this discussion, I have tried to sketch the outlines of a dense and extensive history of the formation of homophobic conservative thinking in Maronite Lebanon aided and abetted by the Jesuit promotion of Thomistic and post-Tridentine theology. As to the creation of Article 534, I hope it is now more understandable why I do not identify Vichy, much less French laïc colonialism as its chief, and certainly not sole, agents. Instead, I argue that like general Lebanese political and religious sectarianism, Article 534 is a specific case of a congenial collaboration of Jesuit Thomistic moral theology and a conservative Maronite ethical and legal koine. Article 534 departs from the model of a more secular code of sexual mores, found in the French Penal Law. Article 534's criminalization of "unnatural" sex acts is also what one might expect, given the growth of sectarian Maronite religious nationalism along with Jesuit sectarian moral theological education. This Maronite intensification of religious identity meant nothing less than resistance to the values of the universalist laïcité of the French Mandate's mission civilsatrice. Thus, while I would not ignore the fact that Article 534 did apparently enter the Lebanese Penal Code in I943, only shortly after Pétain's supposed criminalization of same-sex relations on August 6, I942, it matters enormously how one reads this coincidence. ${ }^{\mathrm{I}} 49 \mathrm{I}$ have attempted to show how Lebanon's history of the influence of Jesuit Thomistic moral education on the Maronite community must be considered as a critical enabling factor: "While the French government in Paris always wanted to shape Lebanon according

I47 Baroudi and Tabar, "Spiritual Authority versus Secular Authority," 225.

I 4 Farha, "Stumbling Blocks," 32.

I49 Makarem, "The Story of HELEM," 99. 
to its own metropolitan laïc image to fall into line with their grand imperial designs, the Jesuit-influenced Maronite Lebanese, at least, did not always share the same goal in either cultural or political matters." $5^{\circ}$

Moreover, the substance of Article 534's homophobia has substantial precolonial Lebanese Christian legal precedents. Intensifying Lebanese sectarianism only made the merger of these two cultural lines of agency ever more seamless. For these reasons, I argue the need to see Article 534 collaboratively engaging both eagerly receptive domestic actors and strategically motivated foreign actors-both contributing to a Maronite community newly formed in colonial times by interaction with the Jesuits.

\section{ACKNOWLEDGMENTS}

Thank you, Dr. Joseph L. Esposito, Esq., Professor Bruce Lincoln, Dr. Ayman Shabana, and Dr. Ellen Hamilton Strenski, for your friendship, timely encouragement, and effective criticism. 